\title{
Reduction and elimination solutions of informal payment in Iran's health system
}

\author{
Farhad Habibi Nodeh ${ }^{1}$, Ibrahim Jafari Pooyan ${ }^{1}$, Iraj Harirchi ${ }^{2}$, Mohammad Arab ${ }^{1 *}$
}

Received: 5 June 2017

Published: 28 Dec 2017

\begin{abstract}
Background: Informal payments can cause delayed access to health care services, forcing people to sell their properties for cost of treatment; and as a result, they lose trust in the health system. Considering the importance of this issue, this study was conducted in 2016 to identify solutions to reduce and eliminate informal payments in Iran's health system.

Methods: Initially, solutions to reduce informal payments were extracted by reviewing resources and searching Persian and Englishlanguage databases including Science direct, PubMed, Scopus, Medline, ISC, Magiran, SID using the following keywords: informal payments, under the table payment, bribes, gratitude payment, and informal payments/fees. Then, Iranian context specific solutions were obtained by performing semi-structured interviews with 19 individuals, who were aware of the problem. Next, the identified strategies were confirmed using Delphi technique and with the participation of 50 experts.

Results: Various solutions were identified and confirmed to reduce or eliminate informal payments in Iran's health system, which are divisible in different economical fields, such as payments to providers based on performance, religious leaders' fatwa (sociocultural), disclosing the offenders' names (legal-political), and using family doctor system (structural).

Conclusion: The proposed solutions can be used by policymakers and managers in the health sector to manage informal payments. Careful identification of health care providers and recipients' motivations and needs can be effective in recognizing and eliminating this phenomenon.
\end{abstract}

Keywords: Informal payment, Elimination informal payment, Bribery, Iran’s health system

Copyright $₫$ Iran University of Medical Sciences

Cite this article as: Habibi Nodeh F, Jafari Pooyan I, Harirchi I, Arab M. Reduction and elimination solutions of informal payment in Iran's health system. Med J Islam Repub Iran. 2017 (28 Dec);31:139. https://doi.org/10.14196/mjiri.31.139

\section{Introduction}

While in most countries the majority of out- of- pocket costs relate to formal and specified payments, in low- and middle-income countries informal payments may form an important part of out- of- pocket expenses (1). Out- ofpocket payment is the weakest and the most unfair method in the health sector. From protection viewpoints against both the risk and equity, this is considered the worst possible method and has the greatest exposure to the catastrophic financial risks for people. Since informal payments are often paid directly to the health service provid-

Corresponding author: Dr Mohammad Arab, arabmoha@tums.ac.ir

1. Department of Health Management and Economics, Public Health School, Tehran University of Medical Sciences, Tehran, Iran.

${ }^{2}$. Deputy of Minister, Ministry of Health, Treatment and Medical Education, Tehran, Iran, \& Medical School, Tehran University of Medical Sciences, Tehran, Iran. er, this type of payment is classified in the category of "using public facilities for personal interests", and thus is considered a type of systematic corruption by definition (2). Another definition that has been used in many studies is as follows: "Informal payments are payments to providers (person or institution) in cash or non-cash outside the framework of official payments and for services covered by public health car e systems, which are free." (3-7). To develop effective strategies to eliminate informal payments and successful implementation of formal payments,

$\uparrow$ What is “already known" in this topic:

Among the main reasons for informal payment in Iran's health care system are weak motivation of the providers and existence of structural problems. Thus, raising tariffs and salaries are vital to eliminate informal payment and its related problems.

$\rightarrow$ What this article adds:

Informal payment in the health care system of Iran has decreased in public inpatient centers after implementation of the Health Reform Plan. Moreover, economic, cultural, structural, and legal solutions have been used to reduce these payments in both the private and public sectors. 
we need to identify factors that cause such payments in the health system. Thus, global studies on informal payments have been rising in recent years (8-11). In different countries, different terms such as bribery, black money, and gray money are used for informal payments (1). Informal payments have become an important and controversial issue in the health sector, particularly in developing and transitional countries in Central and East Europe, the former Soviet Union, Central, East, and South Asia, Africa, and South America (11-13). Informal payments help the policymakers create their own organization and policies indirectly, while they influence people's lives directly with these policies (14). In some countries, this type of payment has become a part of people's culture, and thus eliminating it may be very difficult (15).

In Czech Republic, 59\% of hospital payments is informal (16). Also, the amount of such payments in Slovakia, Bulgaria, and Russia are $60 \%, 43 \%$, and 53\%, respectively $(9,17)$. In some countries, informal payments constitute a significant portion of income per capita. Based on published studies in India and Bulgaria, these payments make up $35 \%$ of monthly income. This amount is $130 \%$ and $40 \%$ in the United States and Albania, respectively (12). Informal payment for inpatient care also makes up a substantial portion of household budget in European countries; this amount is $46 \%$ of the total out- of- pocket in hospitals (18). The study conducted in Greece in 2008 showed that $36 \%$ of patients paid at least one indirect payment to doctors (19).

Studies indicate that informal payments create a continuous relationship between the service provider and the patient, improve employee's morale, avoid the burnout of the health system employees, and allow patients to show respect to service providers by these payments and thank them $(8,20)$. At the same time, such payments may cause various problems for the patients, as they can cause delayed access to health care services, forcing people to sell their properties for cost of treatment; and as a result, they lose trust in the health system $(10,20,21)$. Some studies also revealed that the quality of clinical services is under the influence of informal payments $(20,22)$. Apart from its impact on an individual level, informal payments will also influence health system performance. Its effect on the health care system will be revealed through its impact on service distribution and the resources allocation in this section. This form of payment can also have a positive effect on the health system. For instance, reports indicate that even a small amount of money can motivate the physicians to continue their activities in the public sector (16, 23). Various authors have mentioned different reasons for such payments including cultural problems, lack of investment in the health sector, and lack of supervision and accountability in the health care system (24).

The study conducted by Meskarpour et al. (2016) in Iran indicated that the prevalence of informal payments is $48 \%$ (25). A study conducted by Khodamoradi et al. (2015) found the prevalence of informal payments to be about $30 \%$ in Iran (1). The results of studies in Iran before the implementation of the Health Reform Plan have indicated that lack of physician's income and unreal tariff were the reasons for receiving such payments (15). While one of the objectives of the Health Reform Plan was to modify tariffs in Iran, according to current reports (26), even with the implementation of this plan, this type of payment still exists in Iran's health system, particularly in outpatient and private sectors. In a study conducted by Piroozi et al. in Iran, the findings indicated that informal payments have existed in inpatient sectors before and after the Health Reform Plan (27). Considering the importance of this issue and aiming to help the health system policymakers formulate the necessary reforms, this study aimed at identifying practical solutions to reduce and eliminate informal payments in both outpatient and inpatient sectors of Iran's health system.

\section{Methods}

This descriptive and cross-sectional study was conducted in 3 stages. Initially, by reviewing resources and searching the Persian and English-language databases including Science direct, PubMed, Scopus, Medline, ISC, Magiran, SID, related articles were identified using the following keywords: informal payments, under table payment, bribe, gratitude payment, and informal payments/fees. In this stage, studies on solutions to reduce informal payments in Persian and English languages were used. Finally, 27 articles were studied and their solutions, policy recommendations, and suggestions about reducing informal payments were carefully considered. The second stage was conducting a qualitative study using semistructured interviews and open questions. The research population in this stage was all key informants and stakeholders in this field. The study sample in this stage consisted of 19 people including policymakers and decisionmakers at the macro level of the health system including managers and their assistants who worked in the Ministry of Health $(n=5)$, mid-level managers including heads and managers of public and private hospitals $(n=4)$, in the service delivery level including doctors and nurses $(n=7)$, as well as academic scholars who have conducted research in this field $(n=3)$. An attempt was made to select a sample of all levels of the health system. Snowball sampling was used to select individuals. The selection criteria were people who were aware of the issue and interested in participating in the study. The interviews continued until data saturation. Data were analyzed simultaneously with collecting information and writing it down; content analysis was used for this purpose.

Stage III of this study was conducted to provide practical solutions to reduce and eliminate informal payments in Iran's health system using the Delphi technique. Research community at this level included the combination of academic experts, policymakers, and practitioners aware of the issue. Purposive sampling and snowball sampling methods were used to select the participants. No specific rule exists on selecting the participants, and the number of specialists and participants has usually been less than 50 (often 15 to 20). According to the above explanation and considering the possibility of lack of interest in participation due to busy schedule of the participants, 50 individuals were selected $(28,29)$. 
In the first round of Delphi using 2 previous questionnaires, a questionnaire containing 30 solutions in 4 categories was designed on practical solutions to reduce and eliminate informal payments in Iran. Scoring in the questionnaire was based on Likert scale from 1 (the least agree) to 9 (the most agreed). Scores allocated to each of the solutions were divided into 3 categories as follow: low agreements (1-3), an average agreement (4-6), and high agreement (7-9). More than 70\% agreement for each mechanism was determined to reach consensus. Those solutions that more than $70 \%$ of the respondents highly agreed upon (7-9) were put in the frame as the final solutions; and solutions that more than $70 \%$ of the respondents had low agreement upon were eliminated from the framework. The solutions which attained average agreement (30\%- $70 \%$ agreements) were sent to Delphi members to poll again. In the second round of Delphi, the scores that members had given to each solution and the average score were acquired again, and poll was implemented on the remaining solutions on which there was average agreement. After analyzing the results of the second stage, solu- tions about which more than $70 \%$ of respondents had high agreement (7-9) were selected as the final solutions.

Questionnaires were delivered to the participants either face to face or by email, and they were asked to complete the questionnaire within 2 weeks, if possible. At the first round of Delphi, 45 participants out of 50 in the study, $(90 \%)$ and in the second round of Delphi, 31 out of 45 participants $(68.8 \%)$ completed the questionnaire.

\section{Results}

Results in Table 1 reveal that most of the participants in Delphi study have been academic researchers with specialty in health care management (over 26\%).

In the first round of Delphi, the questionnaire contained 30 solutions in the 4 following categories, which was given to the research community: economic solutions, sociocultural solutions, legal-political solutions, and structural solutions. Table 2 displays proposed solutions and agreement percentage about each solution. According to this table, out of 30 proposed solutions, agreement was

Table 1. Demographic characteristics of the participants

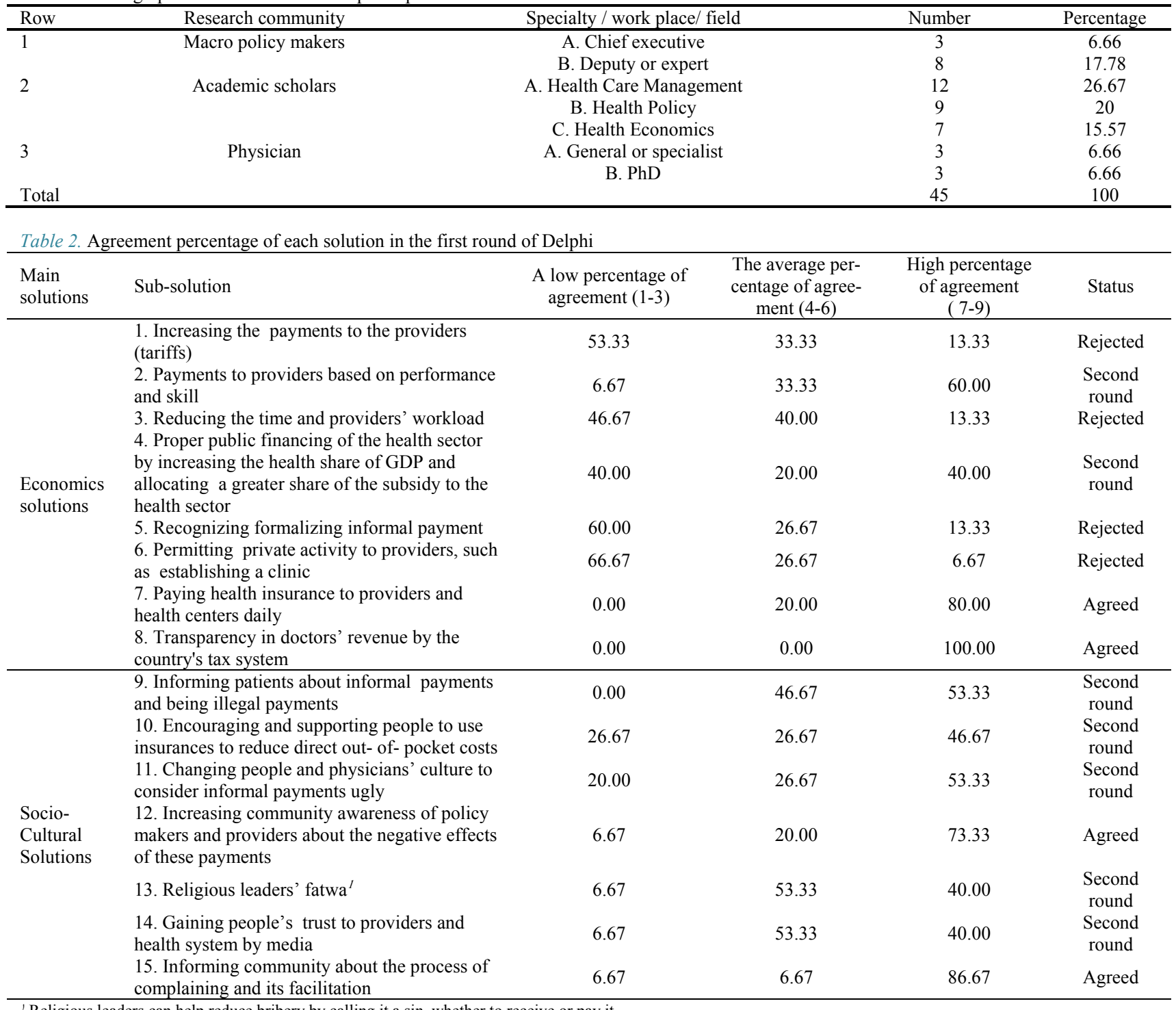




\begin{tabular}{|c|c|c|c|c|c|}
\hline \multicolumn{6}{|l|}{ Table 2. Cntd } \\
\hline \multirow[t]{4}{*}{$\begin{array}{l}\text { Legal-political } \\
\text { solutions }\end{array}$} & $\begin{array}{l}\text { 16. Serious penalties for providers as well } \\
\text { as recipients of services }\end{array}$ & 0.00 & 20.00 & 80.00 & Agreed \\
\hline & $\begin{array}{l}\text { 17. Developing and clarifying legal } \\
\text { framework of patients' rights }\end{array}$ & 46.68 & 26.67 & 26.67 & Rejected \\
\hline & 18. Disclosing the offenders' names & 13.33 & 20.00 & 66.67 & $\begin{array}{l}\text { Second } \\
\text { round }\end{array}$ \\
\hline & $\begin{array}{l}\text { 19. Supervising the right implementation } \\
\text { of laws through neutral organizations }\end{array}$ & 0.00 & 6.67 & 93.33 & Agreed \\
\hline \multirow[t]{11}{*}{$\begin{array}{l}\text { Structural solu- } \\
\text { tions }\end{array}$} & $\begin{array}{l}\text { 20. Increasing the quality of services and } \\
\text { equipment in the public sector }\end{array}$ & 40.00 & 33.33 & 26.67 & Rejected \\
\hline & $\begin{array}{l}\text { 21. Preventing from providers' activity in } \\
\text { both public and private sectors }\end{array}$ & 33.33 & 20.00 & 46.67 & $\begin{array}{c}\text { Second } \\
\text { round }\end{array}$ \\
\hline & $\begin{array}{l}\text { 22. Appropriate regulation to increase } \\
\text { competition between providers }\end{array}$ & 20.00 & 33.33 & 46.67 & $\begin{array}{l}\text { Second } \\
\text { round }\end{array}$ \\
\hline & $\begin{array}{l}\text { 23. Separation of purchaser-provider } \\
\text { through greater use of health insurance }\end{array}$ & 13.33 & 13.33 & 73.33 & Agreed \\
\hline & 24. Using family doctor system & 6.67 & 20.00 & 73.33 & Agreed \\
\hline & $\begin{array}{l}\text { 25. Improving providers' professional } \\
\text { ethics during training }\end{array}$ & 6.67 & 6.67 & 86.67 & Agreed \\
\hline & $\begin{array}{l}\text { 26.Increasing accountability of providers } \\
\text { and managers }\end{array}$ & 13.33 & 33.33 & 53.33 & $\begin{array}{l}\text { Second } \\
\text { round }\end{array}$ \\
\hline & 27. Using per capita payment system & 13.33 & 40.00 & 46.67 & $\begin{array}{c}\text { Second } \\
\text { round }\end{array}$ \\
\hline & $\begin{array}{l}\text { 28. Using health electronic records with } \\
\text { high transparency }\end{array}$ & 13.33 & 6.67 & 80.00 & Agreed \\
\hline & $\begin{array}{l}\text { 29. Increasing patient choice by increas- } \\
\text { ing the number of doctors, especially in } \\
\text { deprived areas }\end{array}$ & 6.67 & 40.00 & 53.33 & $\begin{array}{l}\text { Second } \\
\text { round }\end{array}$ \\
\hline & 30. Increasing patient access to services & 20.00 & 53.33 & 26.67 & Rejected \\
\hline
\end{tabular}

reached on 10 solutions (agreement over 70\%), 13 went into the second round (agreement between $30 \%$ to $70 \%$ ), and 7 were excluded from the questionnaire due to low agreement (less than 30\%).
In the second round of Delphi, 13 solutions, about which there was an average agreement, were given to the research community, the other 7 solutions were agreed upon, and 6 were removed from the questionnaire (Table

Table 3. Percentage of agreement in each solution in the second round of Delphi

\begin{tabular}{|c|c|c|c|c|c|}
\hline $\begin{array}{c}\text { Main } \\
\text { solutions }\end{array}$ & Sub- solution & $\begin{array}{l}\text { A low percentage of } \\
\text { agreement }(1-3)\end{array}$ & $\begin{array}{c}\text { The average percent- } \\
\text { age of agreement (4-6) }\end{array}$ & $\begin{array}{l}\text { High percentage of } \\
\text { agreement }(7-9)\end{array}$ & Status \\
\hline \multirow[t]{2}{*}{$\begin{array}{l}\text { Economics } \\
\text { solutions }\end{array}$} & $\begin{array}{l}\text { 2. Payments to providers based } \\
\text { on performance and skill }\end{array}$ & 0.00 & 25.8 & 74.2 & Agreed \\
\hline & $\begin{array}{l}\text { 4. Proper public financing of the } \\
\text { health sector by increasing health } \\
\text { share of GDP and allocating a } \\
\text { greater share of the subsidy to the } \\
\text { health sector }\end{array}$ & 9.67 & 80.66 & 9.67 & Rejected \\
\hline \multirow[t]{5}{*}{$\begin{array}{l}\text { Sociocultural } \\
\text { solutions }\end{array}$} & $\begin{array}{l}\text { 9. Informing patients that infor- } \\
\text { mal payments are illegal }\end{array}$ & 3.22 & 74.20 & 22.58 & Rejected \\
\hline & $\begin{array}{l}\text { 10. Encouraging and supporting } \\
\text { people to use insurances to reduce } \\
\text { direct out- of- pocket }\end{array}$ & 12.9 & 70.97 & 16.13 & Rejected \\
\hline & $\begin{array}{l}\text { 11. Changing people and physi- } \\
\text { cians' culture to consider infor- } \\
\text { mal payments as sinful }\end{array}$ & 9.67 & 67.75 & 22.58 & Rejected \\
\hline & 13. Religious leaders' fatwa & 0.00 & 29.03 & 70.97 & Agreed \\
\hline & $\begin{array}{l}\text { 14. Gaining people's trust to } \\
\text { providers and health system by } \\
\text { media }\end{array}$ & 0.00 & 29.03 & 70.97 & Agreed \\
\hline $\begin{array}{l}\text { Legal-political } \\
\text { solutions }\end{array}$ & $\begin{array}{l}\text { 18. Disclosing the offenders' } \\
\text { names }\end{array}$ & 6.45 & 22.58 & 70.97 & Agreed \\
\hline \multirow[t]{5}{*}{$\begin{array}{l}\text { Structural } \\
\text { solutions }\end{array}$} & $\begin{array}{l}\text { 21. Preventing from providers' } \\
\text { activity in both public and private } \\
\text { sectors }\end{array}$ & 3.23 & 22.58 & 74.19 & Agreed \\
\hline & $\begin{array}{l}\text { 22. Appropriate regulation to } \\
\text { increase competition between } \\
\text { providers }\end{array}$ & 29.03 & 54.84 & 16.12 & Rejected \\
\hline & $\begin{array}{l}\text { 26.Increasing accountability of } \\
\text { providers and managers }\end{array}$ & 19.35 & 64.52 & 19.35 & Rejected \\
\hline & $\begin{array}{l}\text { 27. Using per capita payment } \\
\text { system }\end{array}$ & 19.35 & 61.30 & 19.35 & Rejected \\
\hline & $\begin{array}{l}29 \text {. Increasing patient choice by } \\
\text { increasing the number of doctors, } \\
\text { especially in deprived areas }\end{array}$ & 3.23 & 25.80 & 70.96 & Agreed \\
\hline
\end{tabular}


Table 4. F solutions to reduce informal payments in Iran's health system

\begin{tabular}{ll}
\hline Solution & \\
\hline \multirow{3}{*}{ Economic } & 1. Payments to providers based on performance \\
& 2. Paying health insurance to providers and health centers daily \\
& 3. transparency in doctors' revenue by the country's tax system \\
\hline \multirow{3}{*}{ Sociocultural } & 1. Increasing community awareness of policymakers and providers about the negative effects of these payments \\
& 2.Informing the community about the process of complaining and its facilitation \\
& 3. Religious leaders' fatwa \\
4. Gaining people trust to providers and health system by media \\
\hline \multirow{3}{*}{ legal-political } & 1. Serious penalties for providers as well as recipients of services \\
& 2. Supervising the right implementation of laws through neutral organizations \\
& 3.Disclosing the offenders' names \\
\hline \multirow{3}{*}{ Structural } & 2. Separation of purchaser-provider through greater use of health insurance \\
& 2. Using family doctor system \\
& 4. Improving providers' professional ethics during training \\
& 5. Preventing from providers' activity in both public and private sectors \\
6. Increasing patient choice by increasing the number of doctors, \\
especially in deprived areas
\end{tabular}

3).

Finally, after performing 2 rounds of Delphi technique, to reduce informal payments, 16 practical solutions were agreed upon in Iran's health system, which were as follow: 3 economic solutions, 4 sociocultural solutions, 3 legal-political solutions, and 6 structural solutions (Table 4).

\section{Discussion}

The present study aimed at identifying solutions to reduce and eliminate informal payments in Iran's health system. A total of 16 solutions (economic, sociocultural, legal-political, and structural) were selected as the final solutions.

In various studies, financial motivation was named as a fundamental solution to reduce informal payments, particularly in developing countries (30-32). In a study by Parsa et al. in 2015 (15), which was conducted before implementation of the health system reform in Iran, raising treatment tariffs was mentioned as the main solution to reduce informal payments. Also, informal payments were decreased after the implementation of the health system reform and current reports $(26,27)$, however, informal payments can still be found in the health system. It seems that by implementing appropriate performance-based payments, whose aim is to motivate health care providers, it may be possible to reduce informal payments more in Iran. Performance-based payment is received in the exchange of service and is used by looking at the quality of services beside other methods, and it has been used in such countries as England, United States, and Turkey (33). Since the fee received in this way is greatly influenced by the volume of activity (34), it seems an appropriate solution to reduce informal payments in deprived areas and in areas where the quality of services is low. In studies conducted by Stepurko et al. in 2013 in Ukraine (35) and Kankeu et al. in 2014 in Cameroon (36), payment based on performance has been considered as a solution and policy option to reduce informal payments. After the implementation of the health system reform, one of the problems and the main reasons for the briberies in the wards from the physicians and policymakers' viewpoint partici- pating in this study was not receiving payments on time, which was due to non-payment of appropriate health insurances. In studies conducted by Lewis in 2007 (12) and Cherecheş et al. (23) in 2013, giving appropriate incentives to providers was proposed as a key solution to reduce informal payments because the daily payment by health insurances that contributes to on time health insurance payments is one of the appropriate motivational methods for health care providers. Another economic solution is doctors' revenue transparency through the country's tax system, which was fully agreed upon. It seems this solution can be used in outpatient and inpatient sectors as well as other sectors and organizations in the country. In a study conducted by Allin et al. (37), increasing accountability and transparency, which is the result of better health care management, was relevant to this study. Also, in Lewis et al. study (12), applying local pressure groups had been considered as a solution to decrease informal payments. In Iran, several organizations such as Health Insurance and Governmental Discretionary Punishments Organization or the Supreme Court can assist the Ministry of Health and the Ministry of Interior as pressure groups ensuring doctors' income transparency and tax receiving system.

In the qualitative part of this study and according to the participants, many people in Iran believe that bribery is not ethical. However, they are not only unaware of its negative effects, but also they consider giving briberies to doctors as a luxury work, but the doctors who receive it know better. In a study conducted by Vian et al. in 2006 (38), focusing on the negative effects of these payments as a policy option had been considered to reduce informal payments in Albania. The results of studies conducted by Cherecheş et al. (23) in 2013, Mokhtari et al. (39) in 2012, and Lewis (17) in 2000 are consistent with those of the current study. Evidence shows that patients and society's awareness will significantly reduce informal payments in the health system, and thus can be named as a governmental expensive and supportive factor, which could drastically reduce out-of-pocket payments in the health system, improve access to services, and ultimately promote equity in the health sector. According to findings of the study by 
Mokhtari et al., patients' awareness of informal payments causes $10 \%$ reduction in briberies (39). Awareness of the society, particularly patients, about the complaint process and facilitating it through the media can be an effective solution to reduce informal payments. Patients' awareness in areas such as recognition of their rights, awareness of services prices, the patients' share from tariffs, and sticking tariff list in the position, where it can be easily visible for all patients, will help reduce informal payments. In a study conducted by Kaitelidou et al. (40) in 2013 in Greece and Gordeev et al. study (41) in Russia in 2014, patients' awareness of their rights and facilitating the process of filing complaints were considered as solutions to reduce informal payments in these 2 countries. In a study conducted in 2015 in 3 countries (Lithuania, Poland, and Ukraine), it was found that setting up a simple, available, and effective complaints system and people's awareness of it can effectively reduce informal payments (42). Involving religious leaders by asking them to give a fatwa that receiving and paying these types of payments are sinful was agreed as another sociocultural solution. According to religious beliefs in Iran, considering that many people do not know that these informal payments are illegal and have negative effects, it seems that religious leaders' intervention would be highly effective in this regard. Most religious leaders have condemned and prohibited bribery by both the briber and the bribe receiver (43). Most of these payments are received outside the health system, thus in addition to informing the public about the illegality of the matter, the religious aspect can also help reduce this phenomenon in Iran. A study conducted in Romania revealed that involvement of churches in moral education can be effective in reducing informal payments (32).

In recent years, negative and massive advertisement about health system providers' performance and income, especially doctors, has been conducted in media. This led to dissatisfaction with the medical community and some doctors identified several reasons for receiving briberies which included lack of trust in the performance and quality of work, income level, and non-compliance with professional ethics, which ultimately led to the loss of the sanctity of medical profession. In studies conducted by Allin et al. (37) in 2006, Rikilikiene et al. (44) in 2014 in Lithuania, and Manea (32) in 2015 in Romania, it was found that obtaining people's trust to health system and health service providers had been considered as a solution to decrease informal payments, confirming the findings of the current study.

After the Health System Reform, "monitoring package executive handbook of implementing health services relative value" was implemented to combat briberies, and it seems its rules have gotten a little stricter, but it has not prevented some doctors to receive bribes yet, especially in outpatient and private sector. Moreover, as some people, especially users of the plastic surgery, attempt to bribe or do not report bribery, determining penalties for such people may also help reduce or eliminate this phenomenon in Iran's health system. The study conducted by Ensor (9) in 2004, Cherecheş et al. (23) in 2013, and Riklikiene et al. (44) in 2014 indicated that imposing heavy fines was con- sidered as a solution to reduce informal payments. In a study conducted in 33 African countries by Kankeu et al., the applying strict and deterrent rules to more access to services and reducing bribery has been emphasized as an effective solution (45). However, in some studies, penalties have not been considered as an appropriate solution to combat corruption in the health system (32). Supervising the right implementation of laws by participants was also approved either in the qualitative part of the study or in the Delphi part. Thus, people believed that the Medical Council will not be able to verify the bribery receptions, as beneficiary organizations and conviction can be transferred to organizations and individuals out of the medical council. The disclosure of offenders as another legal solution was mentioned in Ensor study (9) in 2004, which is consistent with the current study, and it seems that this solution needs further ethical and Islamic investigation.

Purchaser-provider separation has been accepted as one of the main solutions in many countries and various studies. In studies conducted by Billy et al. (46) in 2004 in Georgia, Tatar et al.(47) in 2007 in Turkey, and Gordo et al. (41) in 2014 in Russia, purchaser-provider separation was mentioned as the ultimate solution to reduce informal payments. Studies have shown that in countries where compulsory payments are low and individuals are covered by insurance, there is little or no informal payment. For example, in Germany, the Netherlands, and Sweden, with extensive mandatory payments, any type of informal payments cannot be seen and in France and Croatia there are few informal payments (48). Despite many problems, using family doctor system and referral system in the country can be an important structural solution to cut financial ties between the patient and the provider. We may acknowledge that one of the reasons for lack of briberies in developed countries, particularly in the United Kingdom, is the use of family doctor and referral system. In a study conducted in Turkey in 2007, using family doctor system as the backbone of primary care reform was introduced as a solution to decrease informal payments. Another structural solution obtained in this study was improving professional ethics of health care providers, which can not only be used in the health field but can also prevent infraction in other areas and organizations. In studies conducted in Greece (40) and Ukraine (35) in 2013, improving providers' professional ethics and accountability had been mentioned as one of solutions to reduce briberies. One of the issues raised in Iran's health system was about hospitals using electronic records, which has been proposed in plans related to development of the country (49) and in the health system reform (50), but it has not been fully implemented in all hospitals. In a study conducted by Riklikiene et al. (44) innovative methods such as the use of electronic health records has been emphasized to increase transparency to reduce informal payments. Preventing providers' activity in both the public and private sectors (Dual Practice) is another key finding of the literature review and the qualitative phase of the study. In studies by Billy et al. (51) in 2002, this was mentioned as a solution to decrease informal payment, while in the study conducted by Ensor et al. (9) in 2004, simul- 
taneous doctors' activity in both public and private sectors and the right to have office for doctors were mentioned as an incentive solution to reduce these payments. Finally, as a last structural solution increasing patient choice was obtained to reduce or eliminate bribery. In Iran's health system reform, increasing the number of doctors in deprived areas was implemented as an instruction, and one of the main goals was to eliminate the phenomenon of bribery in these areas. In various studies, having both choice power and receiving high quality services had been mentioned as the main causes of briberies by health care recipients, which it seems have been acquired with implementation of the health system reform in the outpatient and public department, but it needs more investigation and intervention in the outpatient and private sector. In a study conducted by Tomini et al. (52) in 2012, one of the underlying reasons of receiving bribery was long-service system and bypassing the system. In the study conducted by Baji et al. (53) in 2015, informal payments had been made to receive more services and greater access to what was intended by services recipients.

\section{Conclusion}

There is a strong will in Iran's health system to reduce and eliminate the phenomenon of bribery, particularly with the implementation of the health system reform. Reforms in Iran's health system and paying special attention to its financing indicate that health system policymakers are concerned about the community care as well as the dignity of the medical profession. Full implementation of this plan can reduce the payment of bribery in Iran seriously, but its implementation alone is not enough and is only subject to the public sector and inpatient services. Some of the economic, sociocultural, political-legal and related structural problems with informal payments have been resolved in health system, and now health system policymakers can use all the solutions together and gain people, providers, and policymakers cooperation in various fields to eradicate this phenomenon in Iran's health system. Understanding both providers and recipients' needs and motivations of health services can help identify and eliminate this phenomenon. Policymakers' thorough understanding of the effects of these payments as a policy option that everyone has agreed upon will lead to better decisions. Reforms that have been made in this regard should be directed to the poor and vulnerable in the society, which it seems that this aim has been achieved with the implementation of health system reform and paying special attention to deprived areas. The main reason of receiving briberies is financial incentives, which requires the special attention of the policymakers. It can be mentioned that an increase in providers' wages based on their performance and implementing performance-based payment in the health system can help the policymakers reduce this phenomenon in Iran. Education is a way to build trust and understanding between people and is also a means to show the destructive effect of bribery. Education programs should explain how corruption affects people's social status and influences the young generation. Deterrent and stricter rules should be established by the gov- ernment because by implementing the health system reform and paying more to providers, the government has tried to maximize access to services and control bribery, particularly in the public sector. Finally, policymakers should consider that the continuous existence of informal payments eventually becomes a deep and ingrained habit among the people and it would be very difficult and unenforceable to change and eliminate it in the future.

\section{Acknowledgment}

This study was part of a health care management $\mathrm{PhD}$ thesis in Tehran University of Medical Sciences with title of "Analysis of development context and continuity of informal payments in Iran's health system and proposing preventive solutions" and its ethical code is "IR.TUMS.REC.1394.1728. The authors hereby thank the research vice president of Tehran University of Medical Sciences and School of Public Health and also all the people involved in this study.

\section{Conflict of Interests}

The authors declare that they have no competing interests.

\section{References}

1. Khodamoradi A, Rashidian A, Aghlmand S, Arab M, Moini M. Informal Payments and its Related Factors in Urmia Hospitals. Hakim Res J. 2015;17(4):313-21

2. Ghiasipour M, Abolghasem P, Arab M, Mahmoodi M, Abutorabi A. The Analysis of Informal Payments Among Hospitals Covered Under Tehran University of Medical Sciences (TUMS) 2009. Hospit Quart. 2011:10:1-14.

3. Hotchkiss DR, Hutchinson PL, Malaj A, Berruti AA. Out-of-pocket payments and utilization of health care services in Albania: Evidence from three districts. Health Policy. 2005;75(1):18-39.

4. Baschieri A, Falkingham J. Formalizing informal payments: the progress of health reform in Kyrgyzstan. Centr Asian Sur. 2006;25(4):441-60.

5. Radin D. Too Ill to Find the Cure? Corruption, Institutions, and Health Care Sector Performance in the New Democracies of Central and Eastern Europe and Former Soviet Union. East Eur Politics Soc. 2009;23(1):105-25.

6. Özgen H, Sahin B, Belli P, Tatar M, Berman P. Predictors of informal health payments: The example from Turkey. J Med system. 2010;34(3):387-96

7. Tengilimoğlu D, Güzel A, Toygar A, Akinci F, Dziegielewski SF. Informal Payments in Health Systems: Purpose and Occurrences in Turkey. J Social Serv Res. 2015;41(5):684-96.

8. Balabanova D, McKee M. Understanding informal payments for health care: the example of Bulgaria. Health Policy. 2002;62(3):24373

9. Ensor T. Informal payments for health care in transition economies. Soc Sci Med. 2004;58(2):237-46.

10. Falkingham J. Poverty, out-of-pocket payments and access to health care: evidence from Tajikistan. Soc Sci Med. 2004;58(2):247-58.

11. Thompson R, Witter S. Informal payments in transitional economies: implications for health sector reform. Intl J Health Plan Manag. 2000;15(3):169-87.

12. Lewis M. Informal payments and the financing of health care in developing and transition countries. Health Affairs. 2007;26(4):98497.

13. Szende A, Culyer AJ. The inequity of informal payments for health care: the case of Hungary. Health Policy. 2006;75(3):262-71.

14. Cohen N. How Culture Affects Street-Level Bureaucrats' Bending the Rules in the Context of Informal Payments for Health Care: The Israeli Case. Am Rev Public Adm. 2016:1-18.

15. Parsa M, Aramesh K, Nedjat S, Kandi MJ, Larijani B. Informal Payments for Health Care in Iran: Results of a Qualitative Study. Iran J 
Public Health 2015;44(1):79-88.

16. Gaal P, McKee M. Fee-for-service or donation? Hungarian perspectives on informal payment for health care. Soc Sci Med. 2005;60(7):1445-57

17. Lewis MA. Who is paying for health care in Eastern Europe and Central Asia?: World Bank Publications; 2000.

18. Allin S, Davaki K, Mossialos E. Paying for 'free'health care: the conundrum of informal payments in post-communist Europe. Transparency International Global Corruption Report. 2006:62-71.

19. Liaropoulos L, Siskou O, Kaitelidou D, Theodorou M, Katostaras T. Informal payments in public hospitals in Greece. Health Policy. 2008;87(1):72-81.

20. Vian T, Grybosk K, Sinoimeri Z, Hall R. Informal payments in government health facilities in Albania: Results of a qualitative study. Soc Sci Med. 2006;62(4):877-87.

21. Akashi H, Yamada T, Huot E, Kanal K, Sugimoto T. User fees at a public hospital in Cambodia: effects on hospital performance and provider attitudes. Soc Sci Med. 2004;58(3):553-64.

22. Di Tella R, Savedoff WD. Diagnosis corruption: fraud in Latin America's public hospitals: Idb; 2001.

23. Cherecheş RM, Ungureanu MI, Sandu P, Rus IA. Defining informal payments in healthcare: a systematic review. Health Policy. 2013;110(2):105-14.

24. Stepurko T, Pavlova M, Gryga I, Groot W. Empirical studies on informal patient payments for health care services: a systematic and critical review of research methods and instruments. BMC Health Serv Res. 2010;10(1):273

25. Meskarpour-Amiri M, Arani AA, Sadeghi H, Agheli-Kohnehshahri L. Socioeconomic Factors Affecting Informal Payments in the Health Sector. TRAS. 2016;12(47):116-28.

26. National Institute for Health Research. Report of evaluation of healthcare reform in the health sector. 2015.

27. Piroozi B, Rashidian A, Moradi G, Takian A, Ghasri H, Ghadimi T. Out-of-Pocket and Informal Payment Before and After the Health Transformation Plan in Iran: Evidence from Hospitals Located in Kurdistan, Iran. IJHPM. 2017.

28. Landeta J. Current validity of the Delphi method in social sciences. Technol. Forecast Soc Change. 2006;73(5):467-82.

29. Chu HC, Hwang GJ. A Delphi-based approach to developing expert systems with the cooperation of multiple experts. Expert Syst Appl 2008;34(4):2826-40.

30. Lewis M. Informal health payments in central and eastern Europe and the former Soviet Union: issues, trends and policy implications. Funding health care: options for Europe. 2002:184-206.

31. Atanasova E, Pavlova M, Moutafova E, Rechel B, Groot W. Informal payments for health services: the experience of Bulgaria after 10 years of formal co-payments. Eur J Public Health. 2014;24(5):733-

32. Manea T. Medical Bribery and the Ethics of Trust: The Romanian Case. J Med Philos. 2015;40(1):26-43.

33. Molavi Verdkejani H, Kamyabi A, Jabarizadeh A, A. H. Methods of remuneration of general practitioners in the world: a Systematic Review on International Documents. J Med Counc Islam Repub Iran. 2012;30(4):379-89.

34. Kondo KK, Damberg CL, Mendelson A, Motu'apuaka M, Freeman M, O'Neil M, et al. Implementation Processes and Pay for Performance in Healthcare: A Systematic Review. J Gen Intern Med. 2016;31(1):61-9.

35. Stepurko T, Pavlova M, Levenets O, Gryga I, Groot W. Informal patient payments in maternity hospitals in Kiev, Ukraine. The INT J Health Plan M. 2013;28(2):e169-e87.

36. Kankeu Tchewonpi H, Boyer S, Fodjo Toukan R, Abu-Zaineh M. How do supply-side factors influence informal payments for healthcare? The case of HIV patients in Cameroon. University Library of Munich, Germany; 2014.

37. Allin S, Davaki K, Mossialos E. Paying for 'free'health care: the conundrum of informal payments in post-communist Europe. Global Corruption Report. 2006:62-71.

38. Vian T, Burak LJ. Beliefs about informal payments in Albania. Health Policy Plan M. 2006;21(5):392-401.

39. Mokhtari M, Ashtari M. Reducing informal payments in the health care system: Evidence from a large patient satisfaction survey. J Asian Economics. 2012;23(2):189-200.

40. Kaitelidou DC, Tsirona CS, Galanis PA, Siskou OC, Mladovsky P, Kouli EG, et al. Informal payments for maternity health services in public hospitals in Greece. Health policy. 2013;109(1):23-30.

41. Gordeev VS, Pavlova M, Groot W. Informal payments for health care services in Russia: old issue in new realities. Health Economics, Policy and Law. 2014;9(01):25-48.

42. Stepurko T, Pavlova M, Gryga I, Groot W. To pay or not to pay? A multicountry study on informal payments for health-care services and consumers' perceptions. Health Expectations. 2015;18(6):2978-93.

43. www.tebyan.net

44. Riklikiene O, Jarasiunaite G, Starkiene L. Informal patient payments in publicly financed healthcare facilities in Lithuania. Scand. J. Public Health. 2014;42(6):488-96.

45. Kankeu HT, Ventelou B. Socioeconomic inequalities in informal payments for health care: An assessment of the 'Robin Hood'hypothesis in 33 African countries. Soc Sci Med. 2016;151:17386.

46. Belli P, Gotsadze G, Shahriari H. Out-of-pocket and informal payments in health sector: evidence from Georgia. Health Policy. 2004;70(1):109-23.

47. Tatar M, Özgen H, Sahin B, Belli P, Berman P. Informal payments in the health sector: a case study from Turkey. Health Affairs 2007;26(4):1029-39.

48. Tambor M, Pavlova M, Golinowska S, Sowada C, Groot W. The formal-informal patient payment mix in European countries. Governance, economics, culture or all of these? Health Policy. 2013;113(3):284-95.

49. Fifth Five-Year Development Plan of the Islamic Republic of Iran, $73285 / 419$ (2012-2016).

50. Guidelines for health system reform plan. 2014.

51. Belli P, Berman P, Bossert T. Formal and Informal Household Spending on Health: A Multi-country Study in Central and Eastern Europe." Harvard School of Public Health. International Health Systems Group Mimeo. 2002.

52. Tomini S, Groot W, Pavlova M. Informal payments and intrahousehold allocation of resources for health care in Albania. BMC Health Serv. Res. 2012;12(1):17.

53. Baji P, Pavlova M, Gulácsi L, Groot W. Does the Implementation of Official User Charges Help to Eradicate Informal Payments-Lessons to be Learnt from the Hungarian Experience. Frontiers in public health. 2015;3. 